\title{
Analisis Dampak Kawasan Sentra Budidaya Lele Terpadu (KSBLT) Kabupaten Tuban di Kecamatan Merakurak Terhadap Usaha Budidaya Lele di Kecamatan Tuban
}

\author{
Andi Kurniawan ${ }^{1,2,3^{*}}$, Zulkisam Pramudia ${ }^{1,3}$, Abdul Aziz Amin ${ }^{1,3}$, Nurjannah ${ }^{4}$, Wahyu Hidayat ${ }^{2}$ \\ Evi Kurniati ${ }^{1,5}$, Sulastri Arsyad ${ }^{1,2}$, Evellin Dewi Lusiana ${ }^{1,2}$, Gatot Ardian ${ }^{3}$, M. Amenan ${ }^{6}$ \\ ${ }^{1}$ Microbial Resources and Biotechnology Research Group \\ Interdisciplinary Postgraduate Program Universitas Brawijaya \\ ${ }^{2}$ Fakultas Perikanan dan Ilmu Kelautan Universitas Brawijaya \\ ${ }^{3}$ Pusat Studi Pesisir dan Kelautan Universitas Brawijaya \\ ${ }^{4}$ Fakultas MIPA Universitas Brawijaya \\ ${ }^{5}$ Fakultas Teknologi Industri Pertanian Universitas Brawijaya \\ J. Veteran, Ketawanggede Kecamatan Lowokwaru Kota Malang 65145 Jawa Timur \\ ${ }^{6}$ Institut Agama Islam Nahdlatul Ulama Tuban \\ Jl. Manunggal No. 10 - 12 Kecamatan Tuban \\ Kabupaten Tuban 62382 Jawa Timur \\ *andi_k@ub.ac.id \\ DOI: https://doi.org/10.21107/rekayasa.v14i2.11859
}

\begin{abstract}
As one of the efforts to increase production of catfish culture, the Government of Tuban Regency launched the establishment of The Integrated Catfish Cultivation Center Area (ICACA) in Merakurak Sub-District in 2018. The existence of ICACA makes the program to increase catfish aquaculture more coordinated and increase production of catfish cultivation in Tuban Regency. ICCCA not only has an impact on the aquaculture business in Merakurak District, but also in other sub-districts in Tuban Regency. However, studies that explore the impact of ICACA on aquaculture in other areas are rarely reported. This study analyzes the impact of the existence of ICACA on cultivation business in Tuban District in Tuban Regency. This study uses a descriptive method with a mixed method approach (qualitative and quantitative). The results of this study indicate the factors that are the impact of ICACA in Merakurak District on the development of catfish cultivation in Tuban District. Based on the analysis carried out in this study, the implementation of ICACA in Tuban Regency, especially related to the effect of ICACA on catfish cultivation in Tuban District, needs to be directed to the application of sustainable aquaculture based on the empowerment of local community groups.
\end{abstract}

Keywords : catfish; sustainable aquaculture; area; aquaculture center; water resources

\section{PENDAHULUAN}

Indonesia merupakan Negara dengan luas wilayah perairan lebih dari $80 \%$. Kondisi ini menjadikan Indonesia adalah salah satu Negara yang memiliki potensi perikanan terbesar di dunia (Badan Pusat Statistik, 2012; Kementrian Kelautan dan Perikanan, 2012). Produksi perikanan Indonesia yang terus meningkat adalah bidang akuakultur (Bapennas, 2014, Kementrian Kelautan dan Perikanan, 2012; Fidyandini et al., 2020). Wilayah perairan darat Indonesia banyak dimanfaatkan

\section{Article History:}

Received: April, 15 $5^{\text {th }}$ 2021; Accepted: July, 31 2021

Rekayasa ISSN: $2502-5325$ has been Accredited by Ristekdikti (Arjuna) Decree: No. 23/E/KPT/2019 August 8th, 2019 effective until 2023 sebagai lokasi budidaya perairan (Sri et al., 2019). Komoditas perikanan budidaya tawar yang banyak dikembangkan di Indonesia adalah ikan lele (Sahuleka et al., 2020; Sudaryati et al., 2017; Yuniar et al., 2021). Lele banyak dibudidayakan di wilayah pedesaan maupun perkotaan.

Lele juga banyak dikembangkan di Indonesia termasuk di Kabupaten Tuban Provinsi Jawa Timur

\section{Cite this as:}

Kurniawan, A., Pramudia, Z., Amin, A.A., Nurjannah., Hidayat, W., Kurniati, E., Arsyad, S., Lusiana, E.D., Ardian, G \& Amenan, M. (2021). Analisis Dampak Kawasan Sentra Budidaya Lele Terpadu (KSBLT) Kabupaten Tuban di Kecamatan Merakurak Terhadap Usaha Budidaya Lele di Kecamatan Tuban. Rekayasa 14 (2). 288-295.

doi: https://doi.org/10.21107/rekayasa.v14i2.11859

(C) 2021 Andi Kurniawan 
(Ekawati et al., 2021). Untuk bisa meningkatkan usaha budidaya lele dalam mendukung program peningkatan kesejahteraan masyarakat, Pemerintah Kabupaten Tuban melalui Dinas Perikanan dan Peternakan Kabupaten Tuban mencanangkan Kawasan Sentra Budidaya Lele Terpadu (KSBLT) di Kecamatan Merakurak. KSBLT dikembangkan sebagai upaya untuk tidak hanya memadukan dan mensinergiskan bidang-bidang usaha dalam budidaya lele (pembenihan, pendederan, pembesaran, pengolahan), tapi juga budidaya lele dengan kegiatan perekonomian rakyat di bidang yang lain seperti peternakan dan pertanian.

Pengembangan KSBLT Kabupaten Tuban sebenarnya tidak hanya diperuntukkan untuk mengembangkan budidaya lele di Kecamatan Merakurak, tapi juga di kecamatan-kecamatan lain di Kabupaten Tuban. Pengembangan kawasan ini didesain sebagai kawasan inti dalam pengembangan budidaya lele secara terpadu. Oleh karena itu, analisis dampak dari keberadaan KSBLT untuk budidaya kecamatan lain akan memberikan bahan evaluasi dan ide pengembangan yang sangat bermanfaat. Studi analisis seperti ini akan mempertajam pembahasan pengembangan budidaya lele melalui pendekatan pengembangan kawasan sentra akuakultur berkelanjutan (Sustainable Aquaculture). Hasil yang didapat juga akan menjadi acuan penting dalam pengembangan kegiatan kewirausahaan sosial berbasis potensi dan karakteristik masyarakat lokal.

Penelitian ini bertujuan untuk menganalisis dampak keberadaan KSBLT Kabupaten Tuban kepada usaha budidaya di Kecamatan Tuban yang bukan merupakan lokasi utama KSBLT. Kajian yang dilakukan diarahkan untuk dapat menganalisis berdasarkan prinsip dan prakter akuakultur berkelanjutan terutama terkait dengan indikator kesehatan ekosistem perairan sehingga dapat meminimalisir degradasi ekosistem perairan (Nasichah et al., 2016, Kurniawan, 2019; Rahmadhani et al., 2020). Berdasarkan hasil penelitian ini, kegiatan pemberdayaan masyarakat dan keterlibatan dalam kegiatan sosial kemasyarakatan dapat mendukung pengembangan aktivitas kewirausahaan perikanan budidaya dan bidang usaha lainnya seperti yang ada pada KSBLT Kabupaten Tuban.

\section{METODE PENELITIAN}

\section{Lokasi dan Metode Pengambilan Data}

Penelitian ini dilakukan di Kecamatan Tuban, Kabupaten Tuban, Provinsi Jawa Timur pada Mei sampai Agustus 2021. Lokasi ini berjarak kurang lebih $9.8 \mathrm{~km}$ dari lokasi Kawasan Sentra Budidaya Lele Terpadu di Kecamatan Merakurak, Kabupaten Tuban (Gambar 1). Metode yang digunakan adalah deskriptif dengan pendekatan mixed method (kuantitatif dan kualitatif). Pengumpulan data dilakukan melalui deep interview, kuisioner dan Focus Grup Discussion. Responden dari penelitian ini adalah unsur pemerintah yang diwakili oleh Dinas Perikanan dan Peternakan Kabupaten Tuban, pembudidaya lele di Kecamatan Tuban, pelaku usaha pengolahan lele di Kecamatan Tuban dan pemberdaya masyarakat di Kabupaten Tuban.

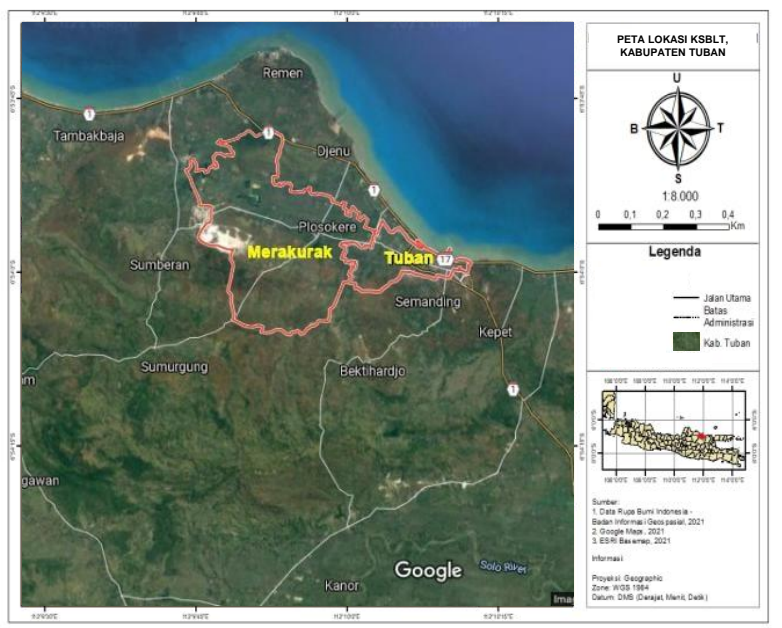

Gambar 1. Lokasi penelitian dan KSBLT Kabupaten Tuban

\section{Analisis Data}

Analisis data dilakukan melalui uji perbandingan (independence $t$-test) dan uji kausalitas (analisis regresi linier) dengan bantuan software STATA. Berikut ini adalah analisis yang dilakukan dalam penelitian ini :

\section{Pemahaman akan KSBLT}

Tingkat pemahaman KSBLT dilakukan dengan merumuskan indikator utama konsep KSBLT dari informasi para stake holders. Pemahaman indikator ini kemudian diujikan kepada pembudidaya lele di Kabupaten Tuban dengan menetapkan standar pemahaman berdasarkan skor yang diberikan (skor 3 dari skala 1 - 5 merupakan nilai batas harapan). Hipotesa yang diujikan dalam uji untuk mengetahui tingkat pemahaman pembudidaya lele terhadap konsep KSBLT adalah:

- HO: $\mu \leq 3$ yang berarti tingkat pemahaman dibawah harapan 
- $\mathrm{H} 1: \mu>3$ yang berarti tingkat pemahaman diatas harapan

Sedangkan uji untuk mengetahui perbedaan respon terhadap tingkat pemahaman pembudidaya akan KSBLT (A) terhadap dampak didasarkan pembudidaya (B) didasarkan pada hipotesa berikut ini:

- $\mathrm{H} 0: \mu \mathrm{A}=\mu \mathrm{B}$ yang berarti dampak yang dirasakan sesuai harapan

- $\mathrm{H} 1: \mu \mathrm{A} \neq \mu \mathrm{B}$ yang berarti dampak yang dirasakan tidak sesuai dengan harapan

\section{Pengaruh KSBLT terhadap usaha budidaya lele}

Analisis pengaruh KSBLT didahului dengan penentukan jenis pengaruh utama yang diukur dalam penelitian berdasarkan informasi dan analisis dari para stake holders. Tingkat pengaruh faktorfaktor ini dianalisis dengan analisis regresi. Hipotesa yang digunakan dalam uji pengaruh media penyebaran dampak KSBLT (Pokdakan, Pondok Pesantren, Jamaah Pengajian, Program Bantuan) dan kondisi internal budidaya lele (Jumlah Kolam, Jumlah Siklus, Lama menjadi pembudidaya, Usia Pembudidaya, Penghasilan Pembudidaya) di Kecamatan Tuban terhadap usaha budidaya lele di Kecamatan Tuban adalah:

- HO: tidak ada pengaruh yang signifikan

- H1: ada pengaruh yang signifikan

\section{Pengetahuan pembudidaya pengelolaan air dan limbah}

tentang

Analisis tingkat pengetahuan dilakukan setelah menentukan indikator pengelolaan air dan limbah yang seharusnya diketahui oleh pembudidaya bedasarkan informasi dari stake holders terkait. Pemahaman indikator ini kemudian diujikan kepada pembudidaya lele di Kabupaten Tuban dengan menetapkan standar pemahaman berdasarkan skor yang diberikan (skor 3 dari skala 1 - 5 merupakan nilai batas harapan). Hipotesa yang diujikan dalam uji untuk mengetahui tingkat pemahaman pembudidaya lele terhadap pengelolaan air dan limbah adalah:

- HO: $\mu \leq 3$ yang berarti tingkat pemahaman dibawah harapan

- $\mathrm{H} 1: \mu>3$ yang berarti tingkat pemahaman diatas harapan

Sedangkan uji untuk mengetahui perbedaan respon terhadap tingkat pemahaman pembudidaya akan pengelolaan air dan limbah (C) pada pelaksanaan pengelolaan air dan limbah (D) didasarkan pada hipotesa berikut ini:
$\mathrm{HO}: \mu \mathrm{C}=\mu \mathrm{D}$ yang berarti pelaksanaan sesuai harapan

- $\mathrm{H} 1: \mu \mathrm{C} \neq \mu \mathrm{D}$ yang berarti pelaksanaan tidak sesuai dengan harapan

\section{Pengaruh KSBLT terhadap pengeloaan air dan limbah budidaya}

Pengaruh kondisi terkait KSBLT terhadap pelaksanaan pengelolaan air dan limbah budidaya dianalisis untuk mengetahui dampak KSBLT terhadap pelaksanaan Akuakultur Berkelanjutan (Sustainable Aquaculture). Untuk menganalisis dampak media penyebaran KSBLT (Pokdakan, Pondok Pesantren, Jamaah Pengajian, Program Bantuan) dan kondisi internal budidaya lele (jumlah kolam, jumlah siklus, lama menjadi pembudidaya, usia pembudidaya, penghasilan pembudidaya) di Kecamatan Tuban terhadap praktek pengelolaan air dan limbah budidaya di dilakukan dengan hipotesa sebagi berikut:

- HO: tidak ada pengaruh yang signifikan

- H1: ada pengaruh yang signifikan

\section{HASIL DAN PEMBAHASAN \\ Pemahaman KSBLT}

Kegiatan budidaya lele di Kabupaten Tuban tidak hanya dilakukan di Kawasan Sentra Budidaya Lele Terpadu (KSBLT) tapi juga di kecamatan lain seperti Kecamatan Tuban (Gambar 2). Pengaruh keberadaan terhadap usaha budidaya lele di Kecamatan Tuban akan sangat dipengaruhi oleh pemahaman pembudidaya lele di kecamatan tersebut (Kunandi et al., 2012; Purwanti \& Susilo, 2019). Hasil eksplorasi yang dilakukan dalam penelitian ini menunjukkan terdapat empat karakteristik utama yang menjadi indikator dari KSBLT, yaitu: 1) pembudidaya lele dikordinasikan atau dihubungkan dalam rangkaitan kegiatan akuakultur, 2) Usaha-usaha dalam budidaya lele seperti pembenihan, pendederan, pembesaran dan pengolahan didesain untuk besinergi, 3) program pembangunan dan pemberdayaan budidaya lele direncanakan dan dilakukan secara berkordinasi, dan 4) usaha budidaya lele menjadi lebih membutuhkan dan dibutuhkan oleh usaha di dibang selain akuakultur. Berdasarkan indikatorindikator ini, maka KSBLT secara umum dapat didefinisikan sebagai kawasan pengembangan budidaya lele yang dilakukan dengan memadukan kegiatan-kegiatan dalam budidaya lele serta usaha 
budidaya lele dengan usaha di bidang lain untuk mengoptimalkan budidaya lele berbasiskan prinsip akuakultur berkelanjutan (Sustainable Aquaculture).
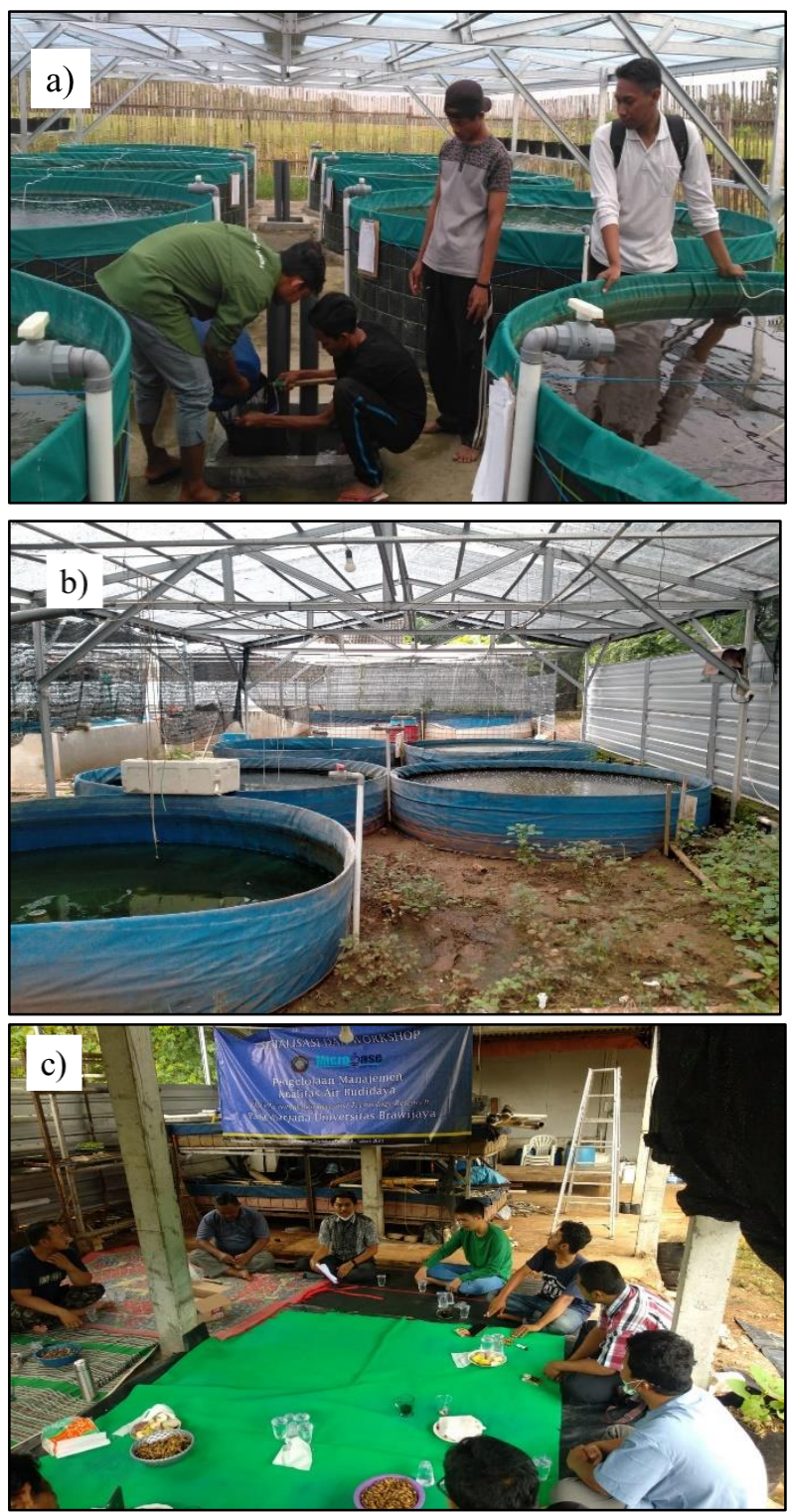

Gambar 2. (a) Kegiatan budidaya lele di Kecamatan

Merakurak (b) sebagai lokasi KSBLT dan di

Kecamatan Tuban, (c) Sosialisasi dan workshop di lokasi KSBLT di Kecamatan Tuban

Analisis tingkat pemahaman pembudidaya lele di Kecamatan Tuban dilakukan sebagai dasar untuk mengetahui pengaruh KSBLT terhadap budidaya lele yang mereka lakukan. Penilaian dilakukan dengan mengkonfirmasi pemahaman pembudidaya terhadap 4 indikator KSBLT. Hasil uji $\mathrm{t}$ untuk satu sample (One-sample t-test) menunjukkan nilai $p$-value yang lebih kecil dari 0,05 (Tabel 1). Hasil ini mengindikasikan kalau kondisi yang ada adalah tolak HO. Analisis ini menunjukkan kalau rata-rata tingkat pemahaman pembudidaya lele di Kecamatan Tuban atas KSBLT diatas harapan. Pembudidaya lele di Kecamatan Tuban juga dapat memahami esensi dari KSBLT walaupun tidak menjadi lokasi dari KSBLT.

Tabel 1. Hasil Analisis Tingkat Pemahaman KSBLT

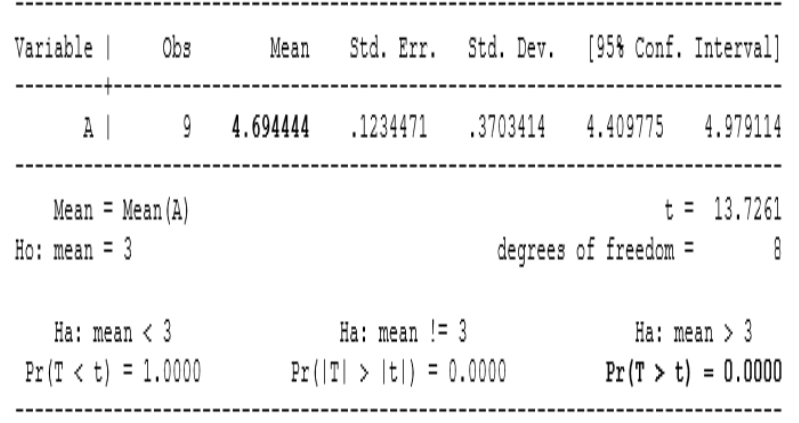

\section{Pengaruh KSBLT terhadap usaha budidaya lele}

Pengaruh tingkat pemahaman pembudidaya lele akan KSBLT terhadap usaha budidaya lele yang mereka lakukan kemudian dianalisis dengan menggunakan Uji t dua sampel (Tabel 2). Variabel yang dibandingkan adalah tingkat pemahaman pembudidaya (A) dan dampak yang pembudidaya rasakan (B). Hasil analisis tersebut menunjukkan kalau nilai $p$-value adalah $0.0000(<0.05)$ yang menunjukkan kondisi tolak H0. Hasil ini mengindikasikan kalau dampak yang dirasakan oleh pembudidaya lele di Kecamatan Tuban akan adanya KSBLT di Kecamatan Merakurak masih dibawah harapan.

Tabel 2. Hasil Analisis Untuk Dampak Keberadaan KSBLT

\begin{tabular}{|c|c|c|c|c|c|c|}
\hline Variable | & $\mathrm{Obs}$ & Mean & Std. Err. & Std. Dev. & [958 Conf. & Interval] \\
\hline A I & 9 & 4.694444 & .1234471 & .3703414 & 4.409775 & 4.979114 \\
\hline B $\mid$ & 9 & 3.569444 & .1615237 & .484571 & 3.19697 & 3.941919 \\
\hline combined I & 18 & 4.131944 & .1683349 & .7141843 & 3.776789 & 4.4871 \\
\hline $\operatorname{diff} \mid$ & & 1.125 & .2032956 & & .6940326 & 1.555967 \\
\hline $\operatorname{diff}=$ & $\ln (\mathrm{A})$ & nean (B) & & & & $=5.5338$ \\
\hline Ho: diff $=$ & & & & degrees & of freedom & 16 \\
\hline
\end{tabular}

Ha: diff $<0$ Ha: diff ! $=0 \quad$ Ha: diff $>0$ $\operatorname{Pr}(\mathbb{T}<t)=1.0000 \quad \operatorname{Pr}(|\mathbb{T}|>|t|)=0.0000 \quad \operatorname{Pr}(T>t)=0.0000$

Usaha budidaya lele di Kecamatan Tuban memang terstimulasi dengan adanya KSBLT, hanya saja dampak utama (peningkatan skala budidaya, peningkatan hasil panen, kemudahan mendapatkan sarana dan prasarana, efisiensi waktu budidaya, efisiensi pakan (FCR) dan keberadaan program pemerintah secara umum masih dibawah harapan. Dampak utama yang dirasakan paling bermanfaat dari keberadaan KSBLT adalah peningkatan skala 
budidaya dan ketersediaan tempat atau pihak untuk belajar cara membudidayakan lele. Hasil-hasil ini mengindikasikan kalau upaya-upaya untuk mendorong perkembangan budidaya lele di wilayah sekitar KSBLT perlu ditingkatkan sehingga keberadaan KSBLT dapat lebih mendorong perkembangan usaha budidaya lele di Kabupaten Tuban secara keseluruhan.

Penelitian ini mengindikasikan kalau dampak adanya KSBLT untuk budidaya lele di kecamatan lain di Kabupaten Tuban terutama dimediasi oleh keterlibatan pembudidaya lele dalam kegiatan kelompok masyarakat. Hasil ini menunjukkan kalau keterlibatan dalam kegiatan sosial kemasyarakatan di Kabupaten Tuban dapat mendukung pengembangan aktivitas kewirausahaan dan program pemerintah. Faktor-faktor utama yang teridentifikasi menjadi sarana penyebaran dampak KSBLT adalah keterlibatan di kelompok pembudidaya ikan (Pokdakan), pengalaman menempuh pendidikan di pondok pesantren, keterlibatan dalam kelompok atau jamaah pengajian dan akses untuk mendapatkan bantuan program pemerintah terkait budidaya lele. Tingkat dampak yang diberikan dari faktor-faktor ini juga dianalisis dalam penelitian ini (Tabel 3).

Tabel 3. Analisis Perbandingan Faktor yang Memfasilitasi Penyebaran Dampak KSBLT

\begin{tabular}{|c|c|c|c|c|c|c|c|}
\hline Source 1 & ss & df & \multicolumn{2}{|c|}{ MS } & & \multirow{4}{*}{$\begin{array}{l}\text { Number of obs } \\
F(3, \quad 5) \\
\text { Prob }>\text { F } \\
\text { R-squared } \\
\text { Adj R-squared } \\
\text { Root MSE }\end{array}$} & \multirow{4}{*}{$\begin{array}{l}=\quad 9 \\
=\quad 0.22 \\
=0.8807 \\
=0.1152 \\
=-0.4157 \\
=\quad .57655\end{array}$} \\
\hline Model & .2164351 & 3 & \multirow{2}{*}{\multicolumn{2}{|c|}{$\begin{array}{l}.072145062 \\
.332407407\end{array}$}} & & & \\
\hline Residual & 1. & 5 & & & & & \\
\hline Total & 1.87847222 & 8 & .234 & 09028 & & & \\
\hline B & Coef. & std. $E_{1}$ & rr. & t & $P>|t|$ & [95\& Conf. & Interval] \\
\hline $\begin{array}{c}\text { Pokdaka_n } \\
\text { Ya }\end{array}$ & .1898148 & .43683 & & 0.43 & 0.682 & -.9331102 & 1.31274 \\
\hline Mondok_n & & & & & & & \\
\hline Yā & .2777778 & $.47074 \mathrm{~S}$ & & 0.59 & 0.581 & -.932 & 1.487877 \\
\hline$\underset{Y_{a}^{-}}{J a m a h}$ & -.0833333 & .40768 & & -0.20 & 0.846 & -1.13131 & .9646437 \\
\hline $\begin{array}{c}\text { Bantuan_n } \\
\text { Ya } \\
\text { cons }\end{array}$ & & & & & & & \\
\hline _co & 3.481481 & .28288 & & 12.31 & 0.000 & 2.754302 & 4.208661 \\
\hline
\end{tabular}

Hasil analisis pada Tabel 3 menunjukkan kalau $p$-value untuk semua variabel diatas $5 \%$. Hasil ini mengindikasikan kalau antara semua faktor utama yang menjadi jalan penyebaran dampak KSBLT (Pokdakan, Pesantren, Pengajian, Bantuan Pemerintah) memberikan pengaruh yang relatif sama dalam menyebarkan dampak keberadaan KSBLT bagi pembudidaya lele di Kecamatan Tuban. Fenomena menarik yang diungkap dalam penelitian ini adalah media yang dirasakan memberikan pengaruh lebih dari dari yang lain adalah kedekatan dengan pondok pensantren, keterlibatan dalam Pokdakan dan keberadaan bantuan pemerintah.
Hasil ini mengindikasikan kalau dalam induksi teknologi dan peningkatan kewirausahaan sosial terkait usaha budidaya lele di Kabupaten Tuban, strategi terbaik yang bisa dilakukan adalah memperkuat bantuan program pemerintah yang disalurkan melalui kelompok usaha dan pondok pensantren sebagai motor pemberdayaan masyarakat.

Dampak KSBLT di Kecamatan Merakurak kepada pembudidaya ikan juga dipengaruhi dari kondisi internal usaha budidaya lele di Kecamatan Tuban. Kondisi internal yang menjadi faktor utama dalam medorong pembudidaya lele di Kecamatan Tuban untuk menerima dampak dari keberadaan KSBLT adalah jumlah kolam, jumlah siklus budidaya per tahun, lama menjadi pembudidaya lele, usia pembudidaya dan penghasilan pembudidaya. Tingkatan dampak yang diberikan dari faktor-faktor ini dalam mendorong penyebaran dampak KSBLT dianalisis dalam penelitian ini (Tabel 4).

Tabel 4. Analisis Tingkatan Pengaruh Faktor Internal Budidaya Terhadap Dampak KSBLT

\begin{tabular}{|c|c|c|c|c|c|c|}
\hline Source I & SS & \multicolumn{2}{|c|}{ MS } & & \multicolumn{2}{|c|}{ 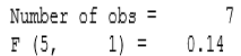 } \\
\hline Model I & 695431799 & $5 \quad .139$ & & & Prob $>\mathbb{F}$ & $=0.9534$ \\
\hline Residual I & 960818201 & 1.96081 & & & $R$-squared & $=0.4199$ \\
\hline Total | & 1.65625 & .27 & 41667 & & Root MSE & $=.98021$ \\
\hline B I & Coef. & Std. Err. & $\mathrm{t}$ & $P>|t|$ & [958 Conf. & Interval] \\
\hline JumlahRolam | & .0659432 & .24237 & 0.27 & 0.831 & -3.013659 & 3.145546 \\
\hline Siklus | & -.0714796 & .5729454 & -0.12 & 0.921 & -7.351441 & 7.208482 \\
\hline Lama $\mid$ & -.0491122 & 1.159936 & -0.04 & 0.973 & -14.78749 & 14.68927 \\
\hline Usia | & .0231203 & .1269943 & 0.18 & 0.885 & -1.590496 & 1.636736 \\
\hline Usia | & 0 & (omitted) & & & & \\
\hline Penghasilan | & $-3.70 e-09$ & $1.95 e-07$ & -0.02 & 0.988 & $-2.48 e-06$ & $2.47 e-06$ \\
\hline Cons I & 2.398499 & 4.671411 & 0.51 & 0.698 & -56.95741 & 61.75441 \\
\hline
\end{tabular}

Hasil analisis pada Tabel 4 menunjukkan kalau pvalue untuk semua variabel di atas $5 \%$. Hal ini mengindikasikan kalau semua faktor mempengaruhi tapi tidak ada faktor yang memberikan pengaruh lebih signifikan dari yang lain. Faktor-faktor internal budidaya lele yang teridentifikasi dalam penelitian ini secara simultan memberikan pengaruh terhadap penyebaran KSBLT pada pembudidaya lele di luar Kecamatan Merakurak yang menjadi lokasi KSBLT. Hasil penelitian ini mengindikasikan kalau semakin banyak jumlah kolam yang dimiliki pembudidaya lele, maka dampak KSBLT semakin meningkat. Jenis usaha yang paling merasakan dampak dari adanya KSBLT adalah usaha pembenihan. 


\section{Pengetahuan Pembudidaya Pengelolaan Air dan Limbah}

Pada prinsipnya penetapan KSBLT adalah upaya dari pemerintah Kabupaten Tuban untuk meningkatkan kesejahteraan masyarakat melalui program Akuakultur Berkelanjutan (Sustainable Aquaculture). Dari eksplorasi yang dilakukan, indikator utama penerapan Akuakultur Berkelanjutan selain aspek keuntungan budidaya lele adalah aspek kelestarian lingkungan. Fokus utama dalam aspek kelestarian lingkungan ini adalah pengelolaan air dan limbah budidaya. Tingkat pemahaman pembudidaya lele akan pengelolaan air dan limbah budidaya setelah ada KSBLT dianalisis dalam penelitian ini (Tabel 5). Pemahaman yang menjadi fokus analisis adalah Dissolved Oxygen (DO), suhu air, $\mathrm{pH}$, pemantauan dan pergantian air kolam, jumlah dan kondisi limbah dan manajemen pakan.

Tabel 5. Analisis Capaian Tingkat Pemahaman Pembudidaya Lele Terhadap Pengelolaan Air dan Limbah

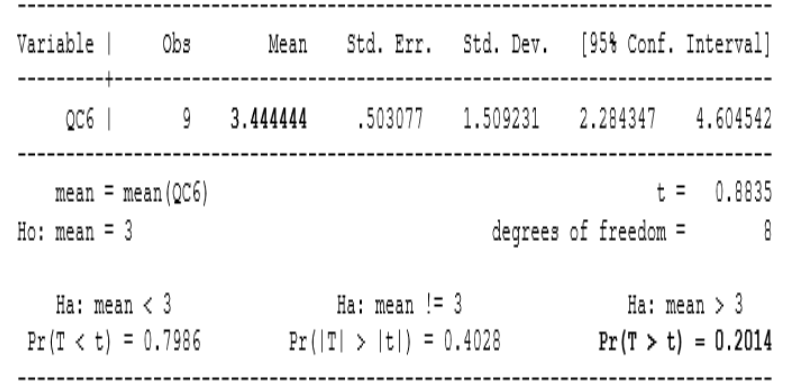

Analisis pada Tabel menunjukkan kalau skor rata-rata pemahaman adalah 3.4 dimana $\mathrm{T}>\mathrm{t}=$ 0.201. Hasil ini menunjukkan kalau tingkat pemahaman pembudidaya lele di Kecamatan Tuban tentang pengelolaan air dan limbah dalam tahap cukup. Pembudidaya dapat memahami prinsipprinsip dasar pengelolaan air dan limbah tapi belum dapat menerapkan sepenuhnya pengetahuan tersebut dalam usaha budidaya yang dilakukan. Salah satu indikasi dari hal ini adalah masih jarangnya instalasi pengolahan limbah budidaya yang dipunyai pembudidaya lele. Pengaruh tingkat pemahaman terhadap pelaksanaan pengelolaan air dan limbah dianalisis dalam penelitian ini (Tabel 6). Hasil analisis yang didapat menunjukkan nilai $\mathrm{p}$ value diatas $5 \%$ yang berarti pemahaman yang ada belum dapat dengan optimal mendorong pelaksanaan pengelolaan air dan limbah sebagai bagian dari praktek Akuakultur Berkelanjutan. Walaupun para pembudidaya lele menyadari potensi dampak negatif limbah budidaya untuk kesehatan lingkungan, tingkat keuntungan usaha budidaya lele belum dapat mendukung penerapan instalasi pengolahan limbah ini.

Tabel 6. Hasil Analisis Pengaruh Tingkat Pengetahuan Terhadap Pelaksanaan Pengelolaan Air dan Limbah

\begin{tabular}{|c|c|c|c|c|c|c|}
\hline Variable | & Obs & Mean & Std. Err. & Std. Dev. & [958 Conf & Interval] \\
\hline C। & 9 & 4 & .168 & .5068969 & 3.610365 & 89635 \\
\hline D I & 9 & 4.055556 & .2635231 & .7905694 & 3.44787 & 4.663241 \\
\hline combined | & 18 & 4.027778 & .1519959 & .6448641 & 3.707094 & 4.348461 \\
\hline $\operatorname{diff} \mid$ & & -.0555556 & .3130397 & & -.71917 & .6080589 \\
\hline $\operatorname{diff}=$ & (C) & $\operatorname{mean}(D)$ & & & & -0.1775 \\
\hline Ho: diff $=$ & & & & degrees & of freedom & 16 \\
\hline $\begin{array}{r}\text { Ha: dif } \\
\operatorname{Pr}(T<t)\end{array}$ & 307 & & $\begin{array}{l}\text { Ha: diff ! } \\
T|>| t||=\end{array}$ & & $\begin{array}{r}\text { Ha: } \\
\operatorname{Pr}(T>\end{array}$ & $\begin{array}{l}\text { iff }>0 \\
=0.569\end{array}$ \\
\hline
\end{tabular}

\section{Pengaruh KSBLT Terhadap Pengelolaan Air dan Limbah}

Media utama dalam mendorong penyebaran pengaruh KSBLT di Kecamatan Merakurak pada usaha budidaya lele di Kecamatan Tuban adalah keterlibatan dalam Pokdakan, hubungan dengan Pondok Pesantren, keikutsertaan dalam jamaah pengajian dan akses ke program bantuan pemerintah. Pengaruh media ini terhadap pengetahuan dan kesadaran akan Akuakultur Berkelanjutan terutama pengelolaan air dan limbah budidaya juga dianalisis dalam penelitian ini (Tabel 7). Analisis pada Tabel 7 menunjukkan kalau nilai pvalue semua variabel diatas $5 \%$. Hasil ini mengindikasikan kalau kondisi yang ada adalah $\mathrm{HO}$ yaitu semua media memberikan pengaruh yang sama. Hal ini berarti dalam penyebaran kesadaran pengelolaan air dan limbah budidaya antara semua media penyebaran dampak KSBLT memberikan pengaruh yang relatif sama.

Pemahaman pembudidaya lele di Kecamatan Tuban yang berada tingkatan cukup belum bisa sepenuhnya mendorong pembudidaya lele menerapkan kondisi ideal pengelolaan air dan limbah sesuai dengan prinsp-prinsip Akuakultur Berkelanjutan. Untuk dapat meningkatkan penerapan Akuakultur Berkelanjutan untuk kesejahteraan masyarakat, diperlukan usaha peningkatan kesadaran dan penerapan pengelolaan air dan limbah budidaya seiring dengan upaya peningkatan keuntungan usaha baik melalui intensifikasi maupun diversifikasi produk olahan lele. 
Tabel 7. Analisis Pengaruh Media Penyebaran KSBLT Terhadap Pengelolaan Air dan Limbah

\begin{tabular}{|c|c|c|c|c|c|c|}
\hline Source I & ss & df & MS & & Number of obs $=$ & 9 \\
\hline $\begin{array}{r}\text { Model } \\
\text { Residual }\end{array}$ & $\begin{array}{l}2.74074074 \\
2.25925926\end{array}$ & $\begin{array}{l}3 \\
5\end{array}$ & $\begin{array}{r}913580247 \\
451851852\end{array}$ & & Prob $>F$ & $\begin{array}{l}=0.2295 \\
=0.548\end{array}$ \\
\hline & & & & & Adf $\mathrm{R}$-squared & $=0.2770$ \\
\hline Total I & 5 & 8 & .625 & & Root MSE & .6722 \\
\hline D I & Coef. & Std. Err. & $\mathrm{t}$ & $P>|t|$ & [958 Conf. & Interval] \\
\hline \begin{tabular}{r|} 
Pokdaka $^{n}$ \\
Ya
\end{tabular} & -.5185185 & .5093098 & -1.02 & 0.355 & -1.827741 & .7907039 \\
\hline$\underset{\mathrm{Ya}^{\mathrm{a}}}{\operatorname{Mondok}}$ & .9444444 & .5488484 & 1.72 & 0.146 & -.4664153 & 2.355304 \\
\hline \begin{tabular}{r|} 
Jamaah_n $^{n}$ \\
$Y \bar{a}$
\end{tabular} & .8333333 & .4753167 & 1.75 & 0.140 & -.388507 & 2.055174 \\
\hline 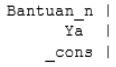 & $\begin{array}{r}0 \\
3.648148\end{array}$ & $\begin{array}{l}\text { (omitted) } \\
.3298168\end{array}$ & 11.06 & 0.000 & 2.800327 & 4.495969 \\
\hline
\end{tabular}

Pengaruh kondisi internal pembudidaya lele di Kecamatan Tuban yang ikut mendorong penyebaran dampak KSBLT (jumlah kolam, jumlah siklus budidaya per tahun, lama menjadi pembudidaya, usia pembudidaya dan penghasilan budidaya) juga dianalisis hubungannya dengan pengelolaan air dan limbah budidaya juga dianalisis di penelitian ini (Tabel 8). Hasilnya menunjukkan kalau nilai $p$-value utk semua variabel di atas $5 \%$. Hasil ini mengindikasikan kalau dalam memberikan pengaruh kepada pengelolaan air dan limbah budidaya kesemua kondisi internal pembudidaya memberikan pengaruh yang relatif sama. Faktor yang memberikan dampak peningkatan adalah lama menjadi pembudidaya dan usia pembudidaya. Hasil ini mengindikasikan kalau penerapan pengelolaan air dan limbah banyak bergantung pada tingkat pengalaman dan kesadaran para pembudidaya lele.

Tabel 8. Analisis Pengaruh Faktor Internal Pembudidaya Terhadap Pengelolaan Air dan Limbah

\begin{tabular}{|c|c|c|c|c|c|c|}
\hline Source I & SS & df & MS & & Number of obs & $=$ \\
\hline & & & & & F ( 5, & 0.04 \\
\hline Model I & .568135844 & 5 & .113627169 & & Prob $>F$ & $=0.9965$ \\
\hline Residual | & 3.06678479 & 1 & 3.06678479 & & $R$-squared & $=0.1563$ \\
\hline & & & & & Adj R-squared & $=-4.0622$ \\
\hline Total | & 3.63492063 & 6 & .605820106 & & Root MSE & $=1.7512$ \\
\hline D I & Coef. & Std. Err. & t & $P>|t|$ & [958 & [nterval] \\
\hline JumlahKolam | & -.0200896 & .4330119 & -0.05 & 0.970 & -5.522028 & 5.481849 \\
\hline Siklus | & -.2939068 & 1.023609 & -0.29 & 0.8 & -13 & 12.71228 \\
\hline Lama | & .7516985 & 2.072311 & 0.36 & 0.778 & -25.57951 & 27.0829 \\
\hline Usia | & .0934243 & .2268848 & 0.41 & 0.751 & -2.78942 & 2.976269 \\
\hline ghasilan | & $-4.93 e-08$ & $3.48 e-07$ & -0.14 & 0.9 & $-4.47 e-06$ & $4.37 \mathrm{e}-06$ \\
\hline _cons | & .3832855 & 8.345823 & 0.05 & 0.971 & -105.6604 & 106.427 \\
\hline
\end{tabular}

\section{KESIMPULAN}

Penelitian ini menganalisis dampak keberadaan Kawasan Sentra Budidaya Lele Terpadu (KSBLT) Kabupaten Tuban di Kecamatan Merakurak terhadap usaha budidaya lele di Kecamatan Tuban. Hasil penelitian ini menunjukkan usaha budidaya lele di Kecamatan Tuban terstimulasi dengan adanya KSBLT. Dampak utama yang ada adalah peningkatan skala budidaya, peningkatan hasil panen, kemudahan mendapatkan sarana dan prasarana, efisiensi waktu budidaya, efisiensi pakan (FCR) dan keberadaan program pemerintah, hanya saja dampak-dampak ini secara umum masih belum optimal. Faktor-faktor utama yang teridentifikasi menjadi sarana penyebaran dampak KSBLT adalah keterlibatan di kelompok pembudidaya ikan (Pokdakan), pengalaman menempuh pendidikan di pondok pesantren, keterlibatan dalam kelompok atau jamaah pengajian dan akses untuk mendapatkan bantuan program pemerintah terkait budidaya lele. Dampak KSBLT di Kecamatan Merakurak kepada pembudidaya ikan juga dipengaruhi dari kondisi internal usaha budidaya lele di Kecamatan Tuban seperti jumlah kolam, jumlah siklus budidaya per tahun, lama menjadi pembudidaya lele, usia pembudidaya dan penghasilan pembudidaya. Kondisi internal pembudidaya memberikan pengaruh yang relatif sama terhadap dampak KSBLT. Hasil ini mengindikasikan kalau penerapan pengelolaan air dan limbah banyak bergantung pada tingkat pengalaman dan kesadaran para pembudidaya lele. Berdasarkan hasil penelitian ini, keterlibatan dalam kegiatan sosial kemasyarakatan di Kabupaten Tuban dapat mendukung pengembangan aktivitas kewirausahaan dan program pemerintah seperti yang ada pada KSBLT Kabupaten Tuban.

\section{DAFTAR PUSTAKA}

Badan Perencanaan dan Pembangunan Nasional. (2014). Kajian Strategi Pengelolaan Perikanan Berkelanjutan. Jakarta: Kementerian Perencanaan Pembangunan Nasional.

Badan Pusat Statistik. (2012). Perkembangan Beberapa Indikator Utama Sosial Ekonomi Indonesia. Jakarta: Badan Pusat Statistik.

Ekawati, A.W., Ulfa, S.M., Dew, C.S.U., Amin, A.A., Salamah, L.N., Yanuar, A.T., Kurniawan, A. (2021). 
Analysis of Aquaponic- Recirculation Aquaculture System (A-RAS) Application in the Catfish (Clarias gariepinus) Aquaculture in Indonesia. Aqaculture Studies, 21, 93-100. http://doi.org/10.4194/2618-6381-v21 301.

Fidyandini, H. P., Elisidana, Y., \& Kartini, N. (2020). Pelatihan Penggunaan Probiotik dan Imunostimulan untuk Pencegahan dan Pengobatan Penyakit Ikan Lele pada Kelompok Pembudidaya Ikan Ulam Adi Jaya Kabupaten Mesuji. Jurnal Sinergi, 1 (8), 50-54. https://doi: http://dx.doi.org/10.23960/jss.v5i2.265.

Kementerian Kelautan dan Perikanan. (2012). Kebijakan Industrialisasi Kelautan dan Perikanan. Jakarta: Kementerian Kelautan dan Perikanan.

Kementrian Kelautan dan Perikanan. (2013). Subsektor Perikanan Budidaya Sepanjang Tahun 2017 Menunjukkan Kinerja Positif. Jakarta : Kementrian Kelautan dan Perikanan.

Kunandi., Arkeman Y., Maulana A. (2013). Strategi Peningkatan Produksi Agroindustri Pembenihan Lele Di Bogor. Jurnal Manajemen dan Agribisnis, 10 1-10. https://doi.org/10.17358/jma.10.1.1-10.

Kurniawan, A. (2019). Ekologi Sistem Akuatik; Fundamen dalam Pemanfaatan dan Pelestarian Lingkungan Perairan. Malang: Universitas Brawijaya Press.

Nasichah, Zahrotun, P. Widjanarko, A. Kurniawan dan D. Arfiati. (2016). Analisis Kadar Glukosa Darah Ikan Tawes (Barbonymus Gonionotus) dari Bendung Rolak Songo Hilir Sungai Brantas. Paper presented at Prosiding Seminar Nasional Kelautan. Universitas Trunojoyo Madura (pp. 328-333).

Purwanti, P., Susilo, E. (2019). Pengembangan Usaha Budidaya Lele Sebagai Kegiatan Off Fishing Di
Glondonggede, Kabupaten Tuban. Journal of Economic and Social of Fisheries and Marine, 06(02): 223-236. http://doi.org/10.21776.

Rahmadhani, L. E., Widuri, L. I., \& Dewanti, P. (2020). Kualitas mutu sayur kasepak (kangkung, selada dan pakcoy) dengan sistem budidaya akuaponik dan hidroponik. Jurnal Agroteknologi, 14(01), 33. https://doi.org/10.19184/j-agt.v14i01.15481.

Rahmadhani, L. E., Widuri, L. I., \& Dewanti, P. (2020). Kualitas mutu sayur kasepak (kangkung, selada dan pakcoy) dengan sistem budidaya akuaponik dan hidroponik. Jurnal Agroteknologi, 14(01), 33. https://doi.org/10.19184/j-agt.v14i01.15481

Sahuleka, M., Apituley, Y. M., \& Bawole, Di. (2020). Strategi pelibatan pemuda dalam pengembangan usaha budidaya keramba jaring apung di teluk ambon dalam. Jurnal Penelitian Sosial Ekonomi Perikanan Dan Kelautan, 4(2), 45-57.

Sri R., Restiana W.A., Lestari L. W. (2019). Pengantar Akuakultur. Semarang: Universitas Diponegoro Press.

Sudaryati, D., Heriningsih, S., \& Rusherlistyani, R. (2017). Peningkatan produktivitaspelompok tani ikan lele dengan teknik bioflok. Jppm: Jurnal Pengabdian Dan Pemberdayaan Masyarakat, 1(2), 109. https://doi.org/10.30595/jppm.v1i2.1695

Yuniar, M., Pratiwi, D. Y., \& Agung, M. U. K. (2021). Penyuluhan daring manajemen kualitas air untuk budidaya ikan dalam ember di desa cipaning kecamatan jatinangor kabupaten sumedang sawa barat. Journal of Community Services, 2(1), 42-46. 